\title{
Historicity of the material concrete in the city of Tlemcen
}

\author{
L. Sail ${ }^{\star}$, F. Ghomari and A. Megnounif \\ Abou Bakr Belkaid University, Tlemcen, Algeria. \\ Accepted 5 January, 2011
}

\begin{abstract}
The relative question to the first uses of the concrete as a material of construction in the domain of building in Algeria, and especially in the city of Tlemcen, is the heart of the work that we intend to publish. The objective of this research is to illustrate the history of the evolution of the use of material concrete in the domain of construction in the city of Tlemcen. The applied methodology is to collect all information relative to the projects of construction made on concrete in the period spanning from 1892 to $\mathbf{2 0 0 5}$ from the archives of the township of Tlemcen, and therefore, reach a bank of data that gathers all information referring to every project of construction in concrete, whose exploitation drove us to distinguish five periods where the processes of construction knew a certain number of evolutions, notably in relation to the historicity of the use of the material concrete. Moreover, inserting this bank of data in a card which situates the city of Tlemcen and while appropriating an adequate software to it, we were able to reach all information concerning the date of the project, society of realization, the materials of construction and processes, graphic documentation, etc.
\end{abstract}

Key words: Archives, concrete, card, history, Tlemcen.

\section{INTRODUCTION}

Humanity, through its evolution, used materials of construction, susceptible to offer comfort, aesthetics, suppleness, stability, resistance and durability to the achieved works, progressively (Torrenti et al., 1999; Dubois, 2005). The concrete, on the basis of cement (Brahma, 1992; Vicat, 2000), answered the set of these requirements. Since the end of the 19th century, while some properties worthy of use thereafter were offered in an extraordinary manner, all materials used ancestrally and extensively were eliminated in the domain of construction (Marcel, 1995).

Therefore, how did humans live with this change? Was this material ever adopted quickly or did it give its proofs a long time ago? What is the process in the history of this material that drove to the fantastic development for it to be used more in the world of construction? What were the conditions for its development? Numerous questions on the history of the use of this enigmatic material are observed and they deserve to be clarified. For the case of

\footnotetext{
*Corresponding author. E-mail: saillatefa@yahoo.fr.
}

the survey that we chose to treat, the context is the city of Tlemcen.

To bring some answers to the calm questions, we collected some information available to the service of the archives of the town hall of Tlemcen in order to identify the process of construction that was adopted, as well as the different used materials, with the goal of characterizing chronologically, the evolution of the use of the material concrete in construction in Tlemcen.

\section{STUDY LITERATURE}

With regards to the study literature, we led a meticulous research where we could collect the data concerning more than fifty projects on one period spanning from the end of the 19th century to the beginning of the 21st century. It is necessary to underline the fact that it is during this period that the concrete marked its evolution as a material of construction in the world (Nachtergal, 1994). Also, during a good part of this period, Algeria was occupied by France, who had put legislative texts in place, permitting a better organization and arrangement 


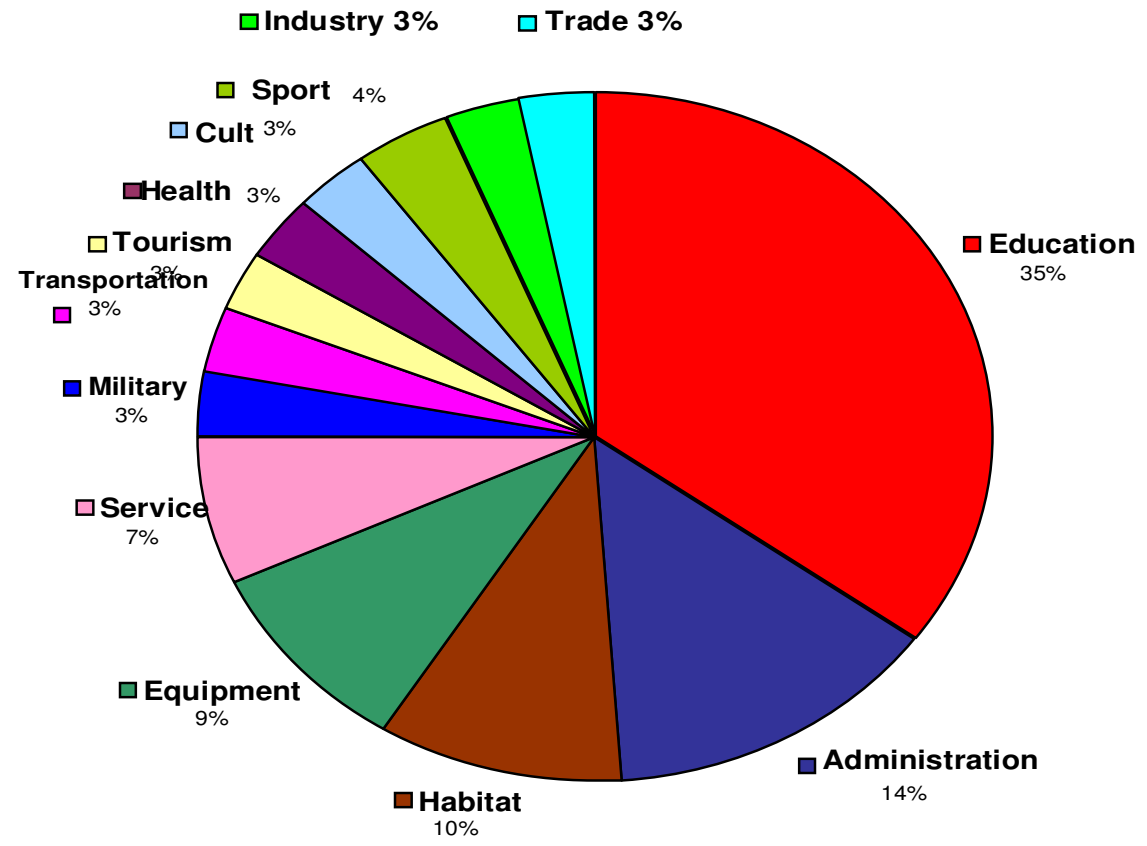

Figure 1. Distribution of the projects by sectors.

of the urban territories, thereby obeying strict procedures that thus concern production of urbanism documents (card, plan, report, decree, etc.) and storage (Olivier, 1980; Poussin, 2005).

After the compilation of the data, we proceeded to their treatment while achieving for every project, a card containing all useful information, such as: situation of the work, date of realization, the undertaken construction, function, used materials, graphic documentation, particularities, etc. The analysis of this information permitted us to find the answers previously to several calm questions.

\section{METHODOLOGICAL APPROACH}

Research within the archives, especially proves to be nit and thus demands a big thoroughness when it is about carrying projects of two or several appellations. It was especially the case in the sector of education. Besides, the studied project's majority includes coins projects annexed to planning and repairing, of which the processes of construction varied. The total number between projects and under projects treaties rises to a hundred and eight. These projects are classified by the chronological order in Appendix 1.

Figure 1 illustrates the different project distributions studied by the sector, of which the most important $(35 \%)$ is the one of education.

The exploitation of the set of these data succeeded in the production of a card that situates the different projects studied according to the ordering recommended by the sector on the one hand, while using their appellation of origin, and presented on the other hand, all relative information to every project that are inserted with the help of hyperlinks on the so-called card. This card has been elaborated with the Autocad software where each sector has been identified in a specific manner by a colour in a plan (Figure 2). The whole graphic documentation has been digitalized with the help of the A0 scanner that is built inside the card with hyperlinks.
In the first time, the projects were implanted in the intramurals. Once this urban space has in itself densities, the projects spread outside the battlements of the city, especially in the southern part, thus preserving the Fertile Crescent situated at the north.

While referring to Figure 3 , if one takes the example of the realization of one primary school (Henri Adès), by a simple click right - Button - on the project illustrated on the card, a window presents itself under the shape of a picture, so the wanted information will be selected automatically from this window.

\section{Use of the concrete in Tlemcen}

The mass of data that have been collected was the object of numerous verifications, due to the worrisomeness of eliminating the potential mistakes of transcription or seizure. It is through the analysis of these data that we intend to answer the objective that we assigned ourselves, which is to know the evolution of the use of the concrete as a material and as a process in time and in space for the studied projects of construction. The relative card analysis for the studied projects permitted us to divide the historicity of the evolution of the use of concrete and its constituent in Tlemcen in five periods.

\section{1st period (1900 to 1930$)$}

During this period, the cement was used like an addition to the hydraulic lime and its use was limited. The distinction of the different types of cement was made by numbering (cement marks $\mathrm{N} \%$, cement marks $\mathrm{N}^{\circ}$, etc.). As for the aggregations, the preference went to the use of the thin sand and granulates calibrated: thick gravel or ballast curdled and broken to the ring (0.06) and very solid gravels to the ring (0.03) (Nachtergal, 1994).

The identification of the granular classes of granulates was taken by their maximal diameter (D) (Domede, 2006). Also, the mixture of the components was achieved there "without addition of water ", after verification by the agent of the company. The stones had to be 


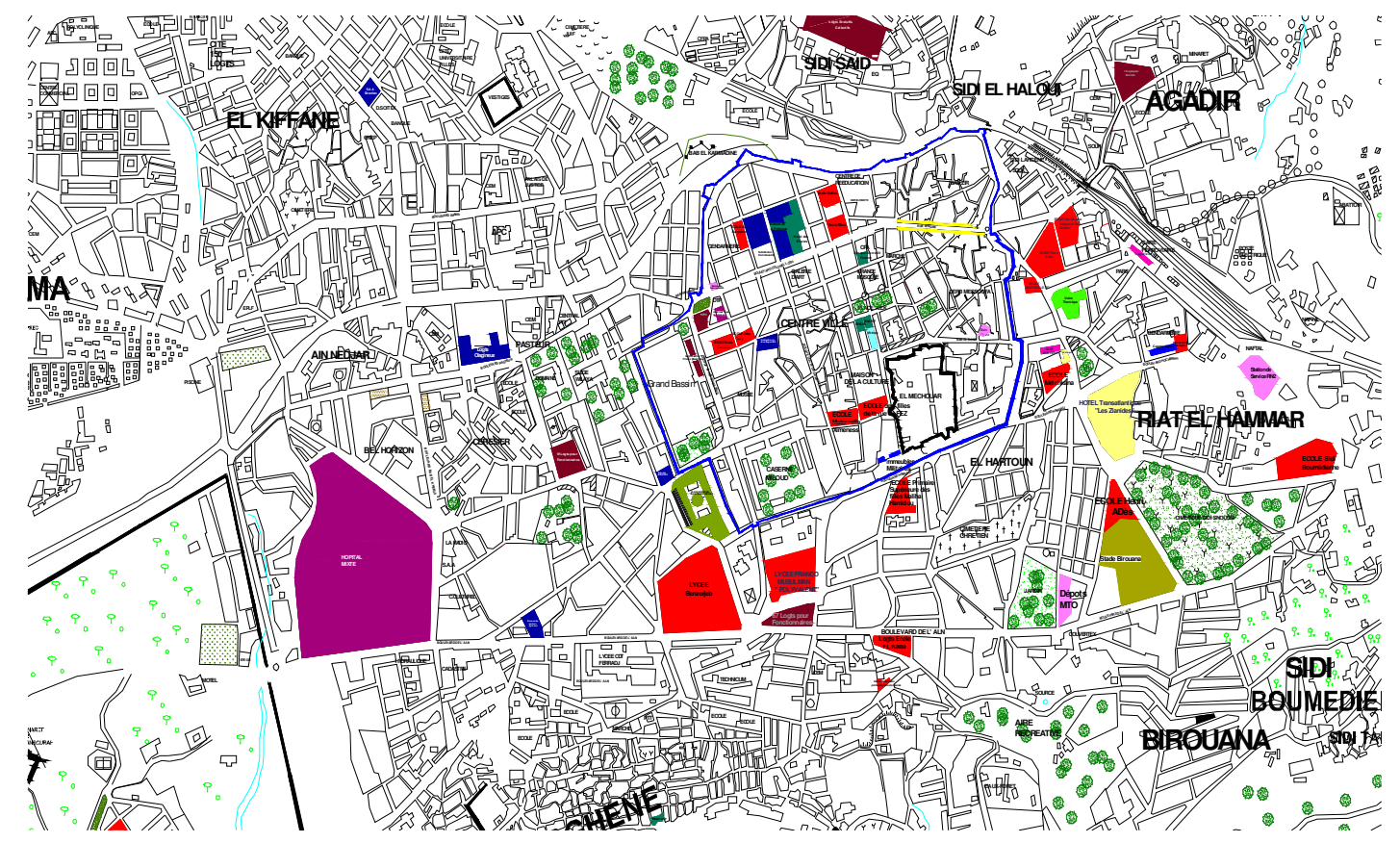

Figure 2. Card presenting the projects studied intra and extramurally.

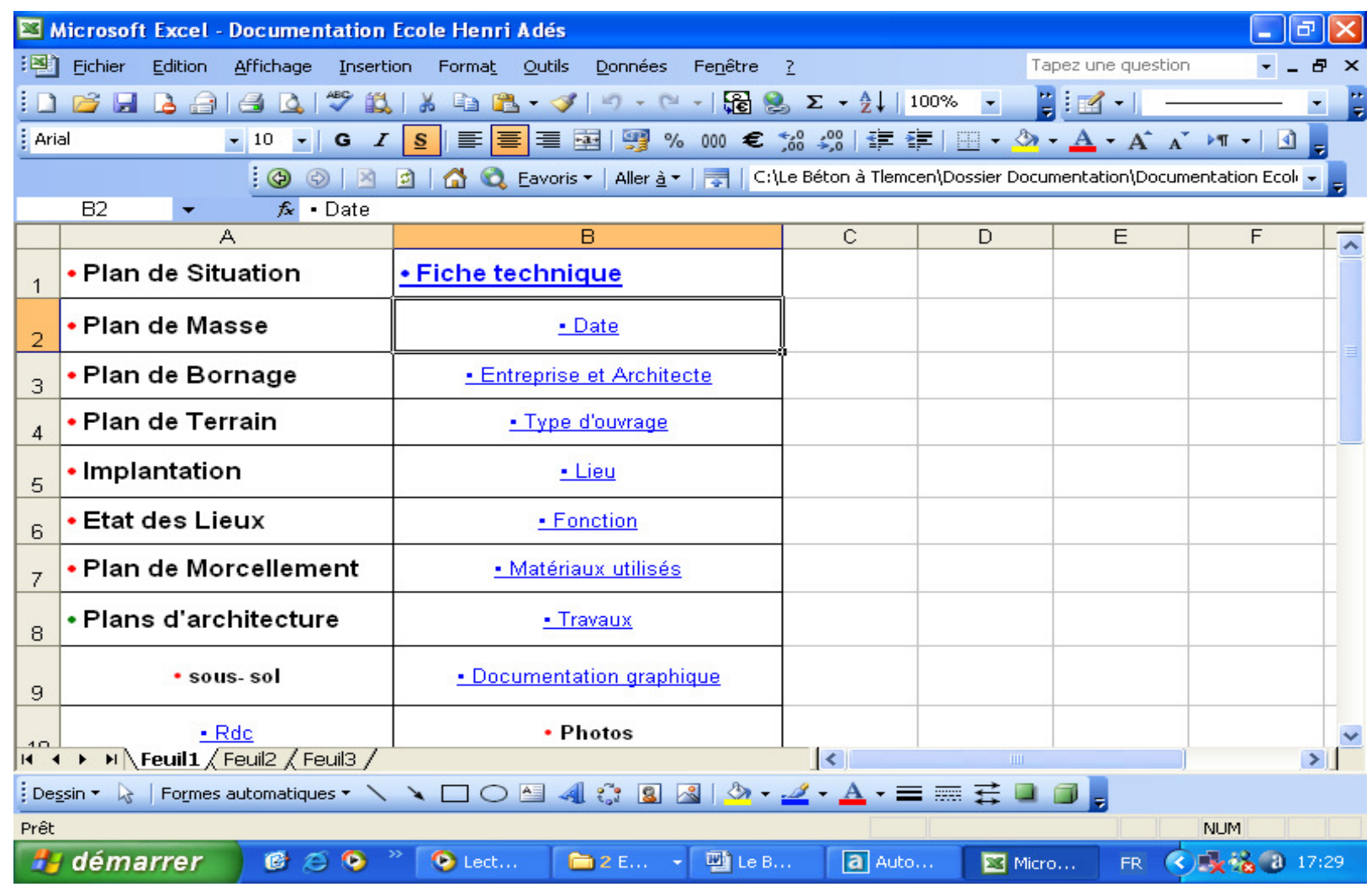

Figure 3. Access to the documentation of the project targeted.

watered before wastage, and then the concrete was used immediately. To the exception of some works of planning made of concrete, we attended to the first use of the skinny concrete in Tlemcen, which is for the confection of tiling in tiles of cement 
Table 1. Source and use of the materials (Period 1900 to 1930).

\begin{tabular}{|c|c|c|}
\hline Material & Source & Nature of the employment \\
\hline $\begin{array}{l}\text { Cement } \\
\text { Cement marks } N^{\circ} 2 \\
\text { Cement marks } N^{\circ} 3\end{array}$ & $\begin{array}{l}\text { Of the Mediterranean; } \\
\text { Of Grenoble; } \\
\text { Analogous to the cement of Rivet and Nice; } \\
\text { Analogous to the cements half slow Vicat }\end{array}$ & $\begin{array}{l}\text { Sealers } \\
\text { Works of foundations } \\
\text { Current works in elevation }\end{array}$ \\
\hline $\begin{array}{l}\text { Hydraulic lime } \\
\text { Fat lime }\end{array}$ & - & Works of foundations \\
\hline $\begin{array}{l}\text { Plaster } \\
\text { Hard stone } \\
\text { Ashlars half hard } \\
\text { Sand }\end{array}$ & $\begin{array}{l}\text { Warehouses of Tlemcen } \\
\text { Of the career of Boumediene } \\
\text { Of the Ravine of Ras el Ain of Oran } \\
\text { Of the career of El Kalaa or Boumediene }\end{array}$ & $\begin{array}{l}\text { Sealers } \\
\text { Masonry works } \\
\text { Masonry works } \\
\text { Realization of mortars }\end{array}$ \\
\hline $\begin{array}{l}\text { Curb-stones } \\
\text { Stones of tuff or materials }\end{array}$ & $\begin{array}{l}\text { Career of Boumediene } \\
\text { Works of demolition }\end{array}$ & $\begin{array}{l}\text { Curb-stones } \\
\text { Blockage and replenishment of the excavations }\end{array}$ \\
\hline
\end{tabular}

tablet. The realization of structures made of reinforced concrete was rare, besides it was called armed cement concrete, and we often met the appellation concrete that was curdled to the hydraulic mortar.

\section{Results of the first period}

Most projects, concerning the sector of education, where we note that the process of construction was used more until 1930, remained the masonry of:

1. Quarry stones, hordes mortar of hydraulic lime and cement.

2. Stones of different sizes or hard stones of Boumediene to the mortar of cement.

3. Bricks hordes to the mortar of cement.

While doing this research, we recovered a certain number of notebooks of the loads revealing the materials used for the composition of the concrete during this period, as well as the new techniques used in construction (Table 1).

\section{2nd period (1931 to 1949$)$}

During these two decades, the studied projects target the sectors of education and facilities.

Standardization on the quality of the constituent was got in place (apparition of new "NPS norms"). Indeed, the cements are classified in relation to the mechanical resistances: cement 20/25 (resistance to traction on 7 and on 28 days) (Nachtergal, 1994), cement 160/250 and 250/315 (resistance to the compression on 7 and on 28 days) (Nachtergal, 1994). Lime 3/5 and the aggregations opposite the thickest diameter (gravel of 20 and $30 \mathrm{~mm}$ granulates) descended from the crushing careers of the region. Also, the mixture concrete was designated according to the type of granulates that it was composed of: curdled concrete or concrete gravels.

\section{Results of the second period}

Concerning the level of construction techniques, the reinforced concrete began to acquire a step on the masonry bearer and used it in the realization of the frame bearer (soles, tie beams, etc.).

The brick made of terracotta is now used for separation with the agglomerate of cement that appears.

The materials used to this time and their source are illustrated on Table 2 .

\section{3rd period (1950 to 1969)}

During this period, we attended to the effort of construction in the sector of continuous education and also attended to works of planning, extension, confrontment and thick repairs since this park begins to grow old and require maintenance and interview.

For recall, this period knew the war of Algeria and its independence (the 05/07/1962). The efforts agreed by France in the sector of building are a means of strategic affirmation of its supremacy during the seven long years of war (1954 to 1962). Then, the first years of independence reveal the will of the country to develop itself and to assure the Algerian citizens of their needs concerning education, health, leisure, etc.

We observe that during this period, new binders are used as the HTS cement, for lime 30/60 and XEH lime.

Also, the used granulates are normalized and identified by granular classes: sand of chalky stone crushing, gravel 8/16, gravel $15 / 25$, gravel of sea $5 / 15$, gravels $6.3 / 25$ and stones $25 / 63$.

The mortars and the concretes diversify to answer new jobs on concrete cast, benched concrete, gigantic concrete, cellular concrete, concrete of cleanliness, etc. Some additions are incorporated there as the pouzzolane, granulated cork and the grain of rice.

\section{Results of the third period}

In process construction, the reinforced concrete became the material that is used more for the works of frame. The evolution of the means of setting and tightening these works facilitated its expansion a lot and contributed to the increase of its mechanical qualities. Besides, a certain interest is dedicated to tightness in order to increase the life span of the structures, while using the bituminous products. Also, we must note that the agglomerate of 
Table 2. Source and use of the materials (Period 1931 to 1949).

\begin{tabular}{llll}
\hline Material & Type & Source & Nature of the employment \\
\hline Lime & $\begin{array}{l}\text { According to the } \\
\text { NP15301S and NP15310S } \\
\text { norms }\end{array}$ & $\begin{array}{l}\text { Of the warehouses in the } \\
\text { region }\end{array}$ & Sealers and concretes \\
$\begin{array}{l}\text { Cement artificial Portland } \\
\text { CPA marks POLIET and } \\
\text { CHAUSSON }\end{array}$ & $160 / 250$ and 250/315 & $\begin{array}{l}\text { Of the Mediterranean } \\
\text { factory of Gargenville }\end{array}$ & Mortars and concretes \\
Gravels & Sand and gravel & $\begin{array}{l}\text { Crushing of the careers' } \\
\text { hard stones in the region }\end{array}$ & $\begin{array}{l}\text { Concrete under foundations } \\
\text { and in elevations }\end{array}$ \\
\hline
\end{tabular}

Table 3. Source and use of the materials (Period 1950 to 1969).

\begin{tabular}{|c|c|c|c|}
\hline Material & Type & Source & Nature of the employment \\
\hline Lime & $\begin{array}{l}30 / 60 \\
\text { XEHS } 30 / 60\end{array}$ & $\begin{array}{l}\text { Of the warehouses in the } \\
\text { region }\end{array}$ & Sealers and concretes \\
\hline Cement & $\begin{array}{l}\text { White terrific cement 259/315; } \\
\text { HTS cement }\end{array}$ & Of the Mediterranean & Mortars and concretes \\
\hline $\begin{array}{l}\text { Cement artificial } \\
\text { Portland }\end{array}$ & $\begin{array}{l}160 / 250 \mid \\
250 / 315 l\end{array}$ & Of the Mediterranean & Mortars and concretes \\
\hline Aggregations & $\begin{array}{l}\text { Gravel of the sea 5/15; } \\
\text { Chalky gravel; } \\
\text { Gravel 8/16 and 15/25; } \\
\text { Gravel 6.3/25; } \\
\text { Stones 25/63 }\end{array}$ & $\begin{array}{l}\text { Crushing the careers' hard } \\
\text { stones in the region }\end{array}$ & $\begin{array}{l}\text { Concrete in foundations and } \\
\text { in elevation }\end{array}$ \\
\hline
\end{tabular}

concrete substitutes itself more and more for the quarry stones of stone and the full brick and hollow firing in the works of masonry. The materials used for the composition of the concretes during this period are less admired by the new French norms (Table 3).

\section{4th period (1970 to 1990$)$}

It is about the period where the independent Algeria put the quinquennial programs opening up on modernity and the economic development in place. The studied projects belong to various sectors (education, habitat, sport and leisures, etc.) where the structures (foundation and thick curve) are achieved exclusively in the concrete of cement. Indeed, the industrialization of the building requires the speed and the resistance raised from the concrete.

\section{Results of the fourth period}

From this period, the lime is reserved to the sealers and the prefabrication became one of the very common construction processes that correspond to the requirements of the moment. Besides, the normalization knew a certain evolution and notably the technical regimentation specifying thus, and in the detail, the act to build. Consequently, this answers the new recommendations.

We note that career granulates could not constantly be sufficient due to increasing demand, and therefore the use of the sea sand at this time was allowed. Also, the set of the used materials were locally available (Table 4).

\section{5th period (1991 to 2005$)$}

During this period, the hydraulic lime disappeared completely, leaving the place exclusively to the cement Portland, whose normalization knew since the beginning of the 21 st century a new flight.

\section{Results of the fifth period}

The classes of resistances have been reviewed in order for the suppliers of the construction materials to be held responsible for the same reason as the masters of the work or the enterprises in the act to construct, while offering a guarantee on the resistance of the cements' compression in 28 days (CPJ 32.5, CPA 42.5 and 52.5).

Also, the lasting development notion requires the preservation of the natural resource and landscape heritage, what contributed to reduce the wild exploitation of the sandpits appreciably in the region and promoting the opening of numerous private and statecontrolled careers.

The consigns of Table 5 used lately some materials that appeared in the files of the works treated. 
Table 4. Source and use of the materials (Period 1970 to 1990).

\begin{tabular}{|c|c|c|c|}
\hline Material & Type & Source & Nature of the employment \\
\hline Hydraulic lime & $30 / 60$ & Of the factories of the region & Sealers \\
\hline Cement CPA & $\begin{array}{l}160 / 250 \\
250 / 315\end{array}$ & Of the factories of the region & Thick works in foundations \\
\hline Plaster & - & Of the factories of the region & Distempers \\
\hline Sea sand & - & Beaches of the region & Mortars and concretes \\
\hline Grinding sand & - & Grinding of hard limestone of the region & Mortars and concretes \\
\hline Crushing sand & - & Crushing of the careers' hard stones of the region & Mortars and concretes \\
\hline
\end{tabular}

Table 5. Source and use of the materials (Period 1991 to 2005).

\begin{tabular}{lcll}
\hline Material & Type & Source & Nature of the employment \\
\hline Cement CPA & 32.5 & Of the factories of the region & Thick works \\
Cement CPA & 42.5 & Of the factories of the region & Thick works and sealers \\
Plaster & - & Of the factories of the region & Distempers \\
Sand & - & Beaches of the region & Mortars and concretes \\
Gravels & - & Grinding of hard limestone of the region & Mortars and concretes \\
\hline
\end{tabular}

\section{RESULTS OF THE RESEARCH}

We note therefore that the concrete as a material and process of construction, known in Tlemcen, as everywhere in the world, is a certain evolution in the domain of the building. We were able to thank the relative archives to the projects achieved within the city of Tlemcen during one century of age, to show the place taken in a progressive manner by this material in the different yards.

Face 4 regroups the results of this striking progression presented during five distinct periods in which the materials and process of construction elders by the products were substituted on the basis of concrete.

During these five distinct periods, we note the evolution of the use of concretes in construction, as well as the receding remark of the use of lime in foundations and elevations.

While analyzing the results illustrated by Figure 4, we distinguish that the use of the lime in construction during the first period was frequent. The first constructions made of concrete started at this time; however the reinforced concrete in the construction was rare.

During the second period, the use of lime moves back little by little, while on the other hand, the constructions made of concrete and reinforced concrete evolved progressively.

For the other periods that follow, the growth of the works achieved in concrete and in reinforced concrete stays hitting, however the structures achieved on the basis of lime are rare.
$[0,1]$ : Weak use (10 to $20 \%)$

$[0,2]$ : Moderate use (20 to $40 \%)$

[0, 3]: Middle use (40 to $60 \%$ )

$[0,4]$ : Big use (60 to $80 \%$ )

$[0,5]$ : Very big use (more than $80 \%$ )

\section{Conclusion}

The apparition of concrete in the world of construction in different domains of building and in public works revolutionized the process and uses of construction practiced a long time ago. As such, new needs appeared with the advent of this material.

Besides, the qualities of this material did not stop improving continuations to the different researches done in this domain. This is due to its composite "property" that gives it, on our days, the merit to be classified among the materials that is used more in the world

Indeed, age was necessary in about one century between the time of deposit of the binder's patent invention designated under the name of "cement artificial Portland" and its use in the confection of the composite mixture (that is, the concrete of cement). The two world wars that humanity knew during the first half of the XXème century were the precursors of a very big consumption in concrete and other materials for the entire city's reconstruction.

In this same context, we tried to draw the historicity of the use of this material in the city of Tlemcen, and also by a research of all construction projects made of concrete 


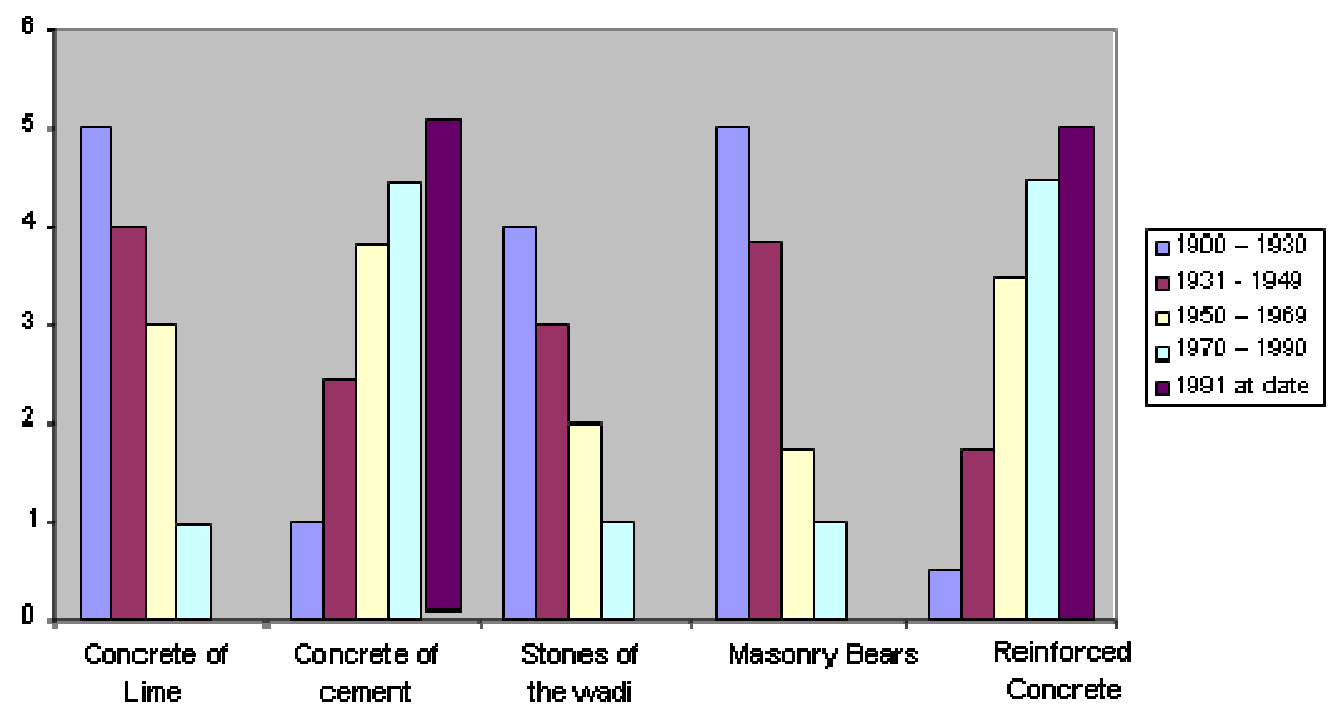

Figure 4. Evolution of the materials and processes of construction.

in this city through the consultation of the township's archived files, while sweeping through this research about one century ago. In this manner, we could gather all relative information to the projects studied by the chronological order in a bank of data that contains technical cards for every treated project as well as the whole available graphic documentation. Accessibility to these data proves to be methodical because all the files are digitalized and a cascade is bound between them. Thus, once the situation card is opened, one is permitted to have access to all information concerning these data while clicking merely on one of the fifty seven studied projects.

With the aid of these information, we could show the place that was taken in a progressive manner by this material in the different yards. We noted that the use of the concrete since the beginning of the XXème century was nearly diffident; however, the use of the hydraulic lime always remained frequent in these features of hardening and resistances declared by the patents established at that time by Louis Vicat (Vicat, 2000).

We distinguished, through this research work, the striking progression of the cement concrete according to five distinct periods generating the substitution of the materials and process of construction elders (the lime, plaster, etc.) in foundations and in elevations.

Besides, we identified the source of the constituent on the basis of the concretes prepared. The dosages of the mortars and concretes varied according to the source of the materials and their availability. The sand of the sea was used at that time, as well as some classes of gravels and stones modified today.
Also, the introverted information revealed that several structures in masonry have been demolished, thereby leaving the place to the new work reconstruction made of concrete and reinforced concrete. This material's innovation imposed itself progressively on all yards and found its application in foundations, as well as in individual house tiles and public buildings that are in the veils of art works or buildings.

\section{REFERENCES}

Brahma A (1992). Le béton, Academic Publication office, university Saad Dahleb, Blida, Algeria. p. 130.

Domede $N$ (2006). Méthode de requalification des ponts en maçonnerie, Toulouse, France, p. 203.

Dubois Pétroff MP (2005). Concrete matters and materials, Paris, France, p. 96.

Marcel PM (1995). Further details of construction labours, Algeria, $p$. 210.

Nachtergal L (1994). Diary of building; INSB, Paris, France. p. 120.

Olivier E (1980). Les Bétons, Edition Modern Company, Paris, France, p. 407.

Poussin $F$ (2005). Faces of the city and construction of knowledge, CNRS Edition, Paris, France, p. 212.

Torrenti JM, Didry O, Ollivier JP, Plas F (1999). The deterioration of concretes, Edition of Hermes sciences publications, Paris, France, p. 214.

Vicat MM (2000). Louis Vicat his life and his works, France, p. 190. 
Appendix 1. Presentation of the studied project.

\begin{tabular}{|c|c|c|c|c|}
\hline $\begin{array}{c}\text { Project } \\
\text { no. }\end{array}$ & Title & $\begin{array}{l}\text { Date of } \\
\text { realization }\end{array}$ & Sector & $\begin{array}{l}\text { References limp } \\
\text { of archive }\end{array}$ \\
\hline \multirow[t]{2}{*}{1} & \multirow{2}{*}{ Construction of a primary school (School Slane - " Ibn Khaldoun " ) } & \multirow{2}{*}{1892} & \multirow{2}{*}{ Education } & 2431 \\
\hline & & & & 2539 \\
\hline 2 & Enlarging the shops of the school (Arabe -Française Décieux) & 1907 & Education & 2569 \\
\hline \multirow{2}{*}{3} & \multirow{2}{*}{ Construction of a primary school (School Sidi Boumédienne). } & \multirow{2}{*}{$13 / 03 / 1912$} & \multirow{2}{*}{ Education } & 2548 \\
\hline & & & & 2549 \\
\hline 4 & $\begin{array}{l}\text { Construction of a building on the floor in border of the appendix of } \\
\text { the MTO nursery }\end{array}$ & 1927 & Service & 10112 \\
\hline 5 & Construction of 11 lodgings & 1927 & Habitat & 10113 \\
\hline 6 & Construction of a thermal factory & 1927 & Industry & 10113 \\
\hline 7 & Construction of an indigenous school of boys "ibn Badiss" & 1930 & Education & 2452 \\
\hline 8 & Construction of an indigenous girls school "Metchkana" & 1930 & Education & 2457 \\
\hline 9 & Construction of a class in the nursery school "Ximenss" & 1933 & Education & 2547 \\
\hline 10 & Amenities and interview in the school (Duffau "Ibn Marzouk") & 1933 & Education & 2447 \\
\hline 11 & Construction of stores & 1933 & Trade & 10129 \\
\hline 12 & Construction of a bank "immeuble du crédit foncier" & 1933 & Equipment & 10129 \\
\hline \multirow{2}{*}{13} & \multirow{2}{*}{$\begin{array}{l}\text { Construction of a primary school superior to that of the girls of } \\
\text { Tlemcen "Maliha Hamidou" }\end{array}$} & \multirow[t]{2}{*}{1935} & \multirow{2}{*}{ Education } & 2438 \\
\hline & & & & 2439 \\
\hline 14 & Construction of a nursery school in the suburb of the station & 1936 & Education & 2452 \\
\hline 15 & Construction of a bank: BNA 527 & 1937 & Equipment & 10145 \\
\hline 16 & Construction of a municipal stage and a swimming pool & 1937 & Sport & 2824 \\
\hline 17 & Thick repairs on the girls school 'Rue de Fez' & 1939 & Education & 2547 \\
\hline 18 & Construction of the Transatlantic hotel "Zianideses " & 1942 & Tourism & 10635 \\
\hline \multirow{2}{*}{19} & \multirow{2}{*}{ Construction of a primary school "Henri Adès" -"Ibn Mssaib" } & \multirow{2}{*}{1950} & \multirow{2}{*}{ Education } & 2465 \\
\hline & & & & 2466 \\
\hline 20 & $\begin{array}{l}\text { Construction of three lodgings for the account of the OLAGINEUX } \\
\text { society }\end{array}$ & 1950 & Administration & 10168 \\
\hline 21 & $\begin{array}{l}\text { Construction of a primary school 'Riat El Hammar' "Tchiali } \\
\text { Mostapha" }\end{array}$ & 1951 & Education & 2569 \\
\hline 22 & Construction of a primary school "Demoiselles" & 1951 & Education & 2611 \\
\hline 23 & Construction of twelve lodgings in the school 'EL Kalaa' & 1951 & Education & 2611 \\
\hline 24 & Construction of a mixed hospital in Tlemcen & $27 / 04 / 1952$ & Health & 10717 \\
\hline \multirow[t]{2}{*}{25} & \multirow[t]{2}{*}{ Construction of a high school for boys -"Ibn Zerdjeb" } & \multirow[t]{2}{*}{ 06/1953 } & \multirow[t]{2}{*}{ Education } & 2436 \\
\hline & & & & 2437 \\
\hline 26 & Construction of a building "Hôtel EL Mansour" & 1954 & Tourism & 10228 \\
\hline 27 & Construction of a Centre of professional education & 1954 & Education & 10228 \\
\hline \multirow{2}{*}{28} & \multirow{2}{*}{ Construction of a European girls school } & \multirow{2}{*}{1955} & \multirow{2}{*}{ Education } & 2438 \\
\hline & & & & 2439 \\
\hline 29 & $\begin{array}{l}\text { Construction of two collective buildings for lodgings of study } \\
\text { (Français - Moslem) }\end{array}$ & 1955 & Habitat & 10228 \\
\hline
\end{tabular}


Appendix 1. Contnd.

\begin{tabular}{|c|c|c|c|c|}
\hline 30 & Construction of an high school "polyvalent" & 1956 & Education & 2441 \\
\hline 31 & Construction of a Hotel in the Stations "la grande poste" & 1956 & Equipment & 10115 \\
\hline 32 & Construction of a Health center & 1956 & Health & 10715 \\
\hline 33 & Construction of a service station in the RN2 & 1956 & Service & 10235 \\
\hline 34 & Heightening of two floors of a building administrative EGA. & 1956 & Administration & 10234 \\
\hline 35 & Construction of a building for the agricultural service installation & 1957 & Administration & 10242 \\
\hline 36 & Construction of temporary offices of the prefecture & 1957 & Administration & 10242 \\
\hline 37 & Construction of two buildings & 1957 & Military & 10238 \\
\hline 38 & Construction of 91 lodgings for civil servants & 1958 & Habitat & 10246 \\
\hline 39 & Construction of a service station in the RN22 & 1958 & Service & 10246 \\
\hline 40 & Construction of 67 lodgings for civil servants & 1958 & Habitat & 10248 \\
\hline 41 & Construction of a lodging to the station of Tlemcen & 1958 & Transportation & 10251 \\
\hline 42 & Construction of collective evolutionary lodgings & 1958 & Habitat & 10251 \\
\hline 43 & Temporary building construction for the subdivision "commissariat" & 1958 & Administration & 10243 \\
\hline 44 & $\begin{array}{l}\text { Construction of a bank B N C I A "national Bank for trade and } \\
\text { industry" }\end{array}$ & 1958 & Equipment & 10244 \\
\hline 45 & Construction of 60 lodgings in Bel air & 1960 & Habitat & 10328 \\
\hline 46 & Construction of a barrack that keeps mobility & 1960 & Military & 21061 \\
\hline 47 & Construction of a mosque in Feddan Sbaa & 1961 & Cult & 10331 \\
\hline 48 & Construction of a reservoir of $500 \mathrm{~m} 3$ in Boudghène & $-10-1961$ & Equipment & 10331 \\
\hline 49 & Construction of a laundry and a drier to the Moorish bath & 1961 & Service & 10328 \\
\hline 50 & Amenities of a building in offices of the INTERCRO & 1961 & Administration & 10328 \\
\hline 51 & Construction of a primary school (Jules Ferry "El Makarri") & $15 / 10 / 1964$ & Education & 2536 \\
\hline 52 & Construction pf a primary school (Pierre Curie "Dar El Hadith") & 1965 & Education & 2539 \\
\hline 53 & Amenities of the stage of Birouana & 1966 & Sport & 2838 \\
\hline 54 & Construction of a station road SNTV & 1969 & Transportation & 10638 \\
\hline 55 & Construction of a direction of unit and lodgings of function for SAA & $21 / 12 / 1980$ & Administration & 10633 \\
\hline ‘56 & Construction of a direction for $\mathrm{DUCH}$ & 1993 & Administration & 1946 \\
\hline 57 & Construction of a Mosque in Oudjlida & 2005 & Cult & 1 \\
\hline
\end{tabular}

